\title{
Correlation of microelements like plasma copper and zinc concentrations with female infertility
}

\author{
Ritu Bawa*, Smita Tyagi
}

Department of Obstetrics and Gynecology, Muzaffaranagar Medical College, Muzaffaranagar, Uttar Pradesh, India

Received: 15 April 2017

Accepted: 08 May 2017

\section{*Correspondence:}

Dr. Ritu Bawa,

E-mail: ritu1.bawa@gmail.com

Copyright: ( ) the author(s), publisher and licensee Medip Academy. This is an open-access article distributed under the terms of the Creative Commons Attribution Non-Commercial License, which permits unrestricted non-commercial use, distribution, and reproduction in any medium, provided the original work is properly cited.

\begin{abstract}
Background: The aim of present study was to determine the role of trace elements copper and zinc and impairment of infertility.

Methods: The study was a randomized, comparative, clinical trial where study group included 74 patients with primary or secondary infertility and control group included 20 patients who were fertile females of reproductive age group having no gynaecological or systemic disease. Venous blood samples were taken and plasma copper and zinc concentrations were measured.

Results: In the normal fertile non-pregnant healthy female's plasma copper ranged from $98.78-169.2$ mcg\% (mean $124.72 \mathrm{mcg} \%$ ). In patients of unexplained infertility plasma copper was found to be low. It ranged from 63.0 - 145.14 mcg\% (mean $95.5 \mathrm{mcg} \%)$ difference being statistically significant, $(\mathrm{P}<0.001)$. The difference in plasma zinc concentration in both group was not statically significant $(\mathrm{P}>0.05)$.

Conclusions: Our results show that copper deficiency might have a role to play in the etiogenesis of otherwise unexplained infertility. We can also conclude that zinc deficiency may not play a significant role in female infertility.
\end{abstract}

Keywords: Copper, Infertility, Zinc

\section{INTRODUCTION}

Motherhood is bliss. Many unfortunate women who are deprived of this eternal pleasure feel a lacuna in their life Dr. Jhaveri wrote in his editorial address in the proceedings of the $16^{\text {th }}$ all India Obstet and Gynae Congress (1972), 'Everything in life and, love is a problem; solution is a child'.

The problem of infertility as to its aetiology and management is still a dilemma for the gynaecologist. To start with cause of infertility was thought to be either blocked tubes or failure of ovulation. Recently it is found that trace elements are also essential for life activities and they are closely related to female infertility abortion and fetal growth. They are calcium, cadmium cobalt, chromium, copper, iron, magnesium, manganese, molybdenum, nickel, lead, rubidium, selenium, vanadium and zinc. In this study, we have undertaken correlation of Plasma copper and zinc concentration with infertility.

Rucker et al postulated that low plasma Copper in the infertile women operates by impairing the structure and function of the supporting collagen in graaffian follicle. ${ }^{1}$ Lindbloom and Hamberger found that Copper stimulated both longitudinal and vascular smooth muscles similar to PGF $2 \alpha$ and they postulated that low plasma Copper in infertile women operates by direct inhibition of ovum transport through fallopian tubes. ${ }^{2}$

Jerome suggested that a defect in DNA synthesis is responsible for infertility in zinc deficiency. ${ }^{3}$ The present study was therefore undertaken with the aim to study the 
relation between plasma levels of Copper and Zinc and unexplained human infertility.

\section{Aims and objectives}

Detection of levels of plasma copper and zinc in primary and secondary infertility and unexplained female infertility.

\section{METHODS}

The patients were selected from the outpatient and inpatient department of Obst and Gynae, Muzaffarnagar Medical College, Muzaffarnagar. All the patients for the study were in the reproductive age group (18-39 years). Study group included the married female of primary or secondary infertility. Control group comprised of married fertile females of reproductive age group. None of the infertile or control subjects were receiving any medication or suffering from any infection during the study.

In all the cases, detailed history was taken regarding the age, age at marriage, duration of infertility, type of infertility, history regarding contraception, details of menstrual history and obstetric history with regard to the number of full term deliveries, still births, type of labour, puerperium and history of MTP or D and C or pelvic inflammatory disease.

A thorough clinical and systemic examination to rule out any systemic disease and per speculum and prevaginal examination was carried out in all patient to exclude pelvic pathology.
Infertility investigations were done in these women in form of follicular study, tubal patency tests and seminal analysis of their partners were done to exclude male factor. Venous blood samples were taken from the infertile women and from 20 fertile non-pregnant women of closely similar age, weight, height and plasma Copper and Zinc concentrations were measured.

\section{RESULTS}

Incidence of unexplained infertility (i.e. those cases where complete investigations show no reason for their infertility was $26(35.14 \%)$ out of which 12 were primary infertility and 14 were secondary infertility.

Table 1: Unexplained infertility in study group.

\begin{tabular}{|c|c|c|c|c|c|c|}
\hline \multirow[t]{2}{*}{ Infertility } & \multicolumn{2}{|c|}{$\begin{array}{l}\text { Total } \\
\text { patient }\end{array}$} & \multicolumn{2}{|c|}{$\begin{array}{l}\text { Primary } \\
\text { infertility }\end{array}$} & \multicolumn{2}{|c|}{$\begin{array}{l}\text { Secondary } \\
\text { infertility }\end{array}$} \\
\hline & No. & $\%$ & No. & $\%$ & No. & $\%$ \\
\hline Unexplained & 26 & 35.14 & 12 & 27.27 & 14 & 46.6 \\
\hline Explained & 48 & 64.86 & 32 & 72.27 & 16 & 53.38 \\
\hline Total & 74 & & 44 & & 30 & \\
\hline
\end{tabular}

In the normal fertile non-pregnant healthy female's plasma Copper ranged from 98.78-169.2 mcg\% (mean $124.72 \mathrm{mcg} \%$; SD 20.74). In patients of unexplained infertility plasma copper was found to be low. It ranged from 63.0 to $145.14 \mathrm{mcg} \%$ (mean $95.5 \mathrm{mcg} \%$ SD 20.42). The difference in serum copper value is highly significant as $\mathrm{P}<0.001$.

Table 2: Comparison of plasma, copper and zinc concentration in control, explained and unexplained infertility.

\begin{tabular}{|ll|l|lllll|}
\hline Group & Total no. & \multicolumn{2}{l}{ Plasma Cu concentration } & \multicolumn{4}{c|}{ Plasma Zn concentration } \\
& of patient & Range & Mean & SD & Range & Mean & SD \\
\hline Control & 20 & $98.78-169.2$ & 124.72 & 20.74 & $90.0-126$ & 107.29 & 10.54 \\
\hline Explained & 48 & $82.57-217.71$ & 123.98 & 32.29 & $85.0-126$ & 106.7 & 11.81 \\
\hline Unexplained infertility & 26 & $63.0-145.14$ & 95.5 & 20.48 & $69.91-133.33$ & 102.74 & 16.30 \\
\hline
\end{tabular}

The difference in plasma Zinc concentration in three groups was not statistically significant $(\mathrm{P}>0.05)$

\section{DISCUSSION}

The problem of infertility still baffles the gynaecologists as this is one of the common cases encountered in practice. The causative factor is yet to be found in case of unexplained infertility which would help in deciding the line of management in these patients.

Copper is essential to human life and health. It plays a key physiological role as the prosthetic element of more than a dozen specific copper protein and has a significant role to play in haem and collagen production and function. The role of copper in human reproduction has not been much investigated. This study was therefore done to find relation between plasma levels of copper and zinc and unexplained infertility.

In the present study incidence of unexplained infertility (that is those cases where complete investigations show no reason for their infertility) was 26 cases $(35.14 \%)$ and was higher in cases of secondary infertility $(46.67 \%)$ as compared to primary infertility $(27.27 \%)$.

M H Soltan and DM Jenkin also found mean plasma copper to be lower (17.3; SE $0.43 \mathrm{mmol} / \mathrm{liter})$ in the 48 infertility women than in 35 control subjects $(22.44$; SE $0.82){ }^{4}$ 
These results suggest that hypocupraemia may be a factor in the aetiology of infertility in these women. Plasma Copper is a sensitive index of tissue copper status and hypocupraemia and hyperceruloplasminea are the earliest detectable manifestation of copper deficiency. ${ }^{5}$ Blood copper concentration is influenced by the level of dietary copper and by the ratio of copper to other components of diet probably molybdenum inorganic sulphate, zinc and iron.

The mechanism by which copper deficiency may be involved in infertility has not yet been explained. Rucker et al postulated that low plasma tissue copper operates by impairing the structure and function of the supporting collagen in the graaffian follicle Lindbloom and Hamberger found that copper stimulated both longitudinal and circular smooth muscles in a manner similar to prostaglandin F2 $\alpha{ }^{1,2}$ They postulated that low plasma copper in infertile women operates by direct inhibition of fallopian tube hindering ovum transport.

The absence of significant difference in plasma zinc concentration between fertile and infertile women in our study does not support the hypothesis of A-L-Saraf et al and Jerome Nriagu that zinc deficiency causes female infertility. ${ }^{3,6}$ Saad A Husain concluded that the increase in copper zinc ratio may have an important aetiological role in the pathogenicity of unexplained infertility which is contradictory to our study. ${ }^{7}$

However, our finding is in accordance with those of $\mathrm{MH}$ Salton and DM Jenkin who found no significant difference in plasma zinc concentration between infertile women and control subjects. ${ }^{8}$

\section{CONCLUSION}

Plasma copper concentration was found to be significantly lower in cases of unexplained infertility as compared to subjects of control group and those of explained infertility. This denotes that copper deficiency might have a role to play in the etiogenesis of otherwise unexplained infertility.

The difference in mean plasma zinc concentration was statistically insignificant. Hence, we can conclude that zinc deficiency may not play a significant role in female infertility.
The association of dietary factors with human infertility remains unclear. Some researchers have reported improved female infertility by consuming some micronutrients. Their deficiency leads to oxidative stress and unexplained infertility.

We need further studies to investigate the interventional strategy of micronutrients supplementation (Group B vitamin, Vitamin $\mathrm{C}$ and $\mathrm{D}$, selenium iron and magnesium) in oxidative status of infertile women.

\section{Funding: No funding sources}

Conflict of interest: None declared

Ethical approval: The study was approved by the Institutional Ethics Committee

\section{REFERENCES}

1. Rucker RB, Parker HE, Ragler JC. Effect of copper deficiency on chick bone collage and selected bone enzymes. J Nutr. 1969;98:57-63.

2. Lindbloom B, Gamberger L, Uleguest $\mathrm{N}$. Differentiated contractility effect of PGE \& F on the isolalid $\mathrm{n}$ circular longitudinal smooth muscle of human ovuduet. Fertile Sterirl. 1978;30:553.

3. Nriagu J. Zinc deficiency in human health. School of Public Health. 2007. Available from: https://pdfs.semanticscholar.org/8d01/a12a1abbffae4 31db613b7f4e12d575258a8.pdf

4. Solton MH, Jenkins DM. Plasma copper and zinc concentration and infertility. Br J Obstet Gynaecol. 1983;90:457-9.

5. Holtzman BA, Charche P, Cordano A, Graham GG. Distribution of Serum copper in copper deficiency. John Hoppin Med J. 1970;126:34-42.

6. Khuload AM. Copper and Zinc status in women with unexplained infertility. AJPS. 2005;2:2.

7. Hussain SA. Copper \& Zinc status in women with unexplained infertility. J Pharm Sci. 2005;2(2):72-5.

8. Soltan MH, Jenkins DM. Maternal and fetal plasma, zinc concentration and fetal abnormality. Br J Obstet Gynaecol. 1982;89:36-8.

Cite this article as: Bawa $\mathrm{R}$, Tyagi S. Correlation of microelements like plasma copper and zinc concentrations with female infertility. Int J Reprod Contracept Obstet Gynecol 2017;6:2351-3. 